\title{
CERVICAL SPINE STENOSIS
}

\author{
By PhIllip Harris, F.R.C.S.E., F.R.C.P.E., F.R.C.S.(Glas), F.R.S.E. \\ Department of Surgical Neurology, Western General Hospital, Edinburgh, and \\ Royal Infirmary, Edinburgh, Scotland
}

Abstract. Increased knowledge of the anatomy, physiology and biomechanics of the cervical spine and the enclosed neural and vascular elements is leading to a better understanding of the importance of cervical spine stenosis, as certain clinical syndromes may ensue and may respond well to operative decompression. The present study was designed to investigate the incidence of cervical spine stenosis in patients who have required surgical treatment for cervical spondylosis, and to evaluate the clinical results.

Key words: Cervical spinal canal stenosis; intermittent neural claudication; computerised axial tomography; cervical spine decompression.

STENOSIS of the cervical spinal canal is almost always present in patients with cervical spondylotic myelopathy, but it can be due to other causes, and may be constitutional and/or secondary. Cervical spondylosis is the most common cause of spinal cord disorder and of cervical nerve root disorders (Brain, I954; Harris, 1963).

Payne and Spillane (1957) state that the normal A.P. diameter of the cervical spinal canal is $17 \mathrm{~mm}$; in cervical spondylosis it is $14.9 \mathrm{~mm}$, and in cervical spondylotic myelopathy $14.4 \mathrm{~mm}$.

Reference will be made to some 45 patients of a personally operated on series of some 500 patients with cervical spondylosis (Table I).

\section{Constitutional}

\section{Pathogenesis}

The reason for constitutional narrowing of the canal is not known. Some authors have stressed the possible significance of excess secretion of human growth hormone in early development possibly causing premature closure of ossification centres. Ossification occurs about the 9th week of gestation, in each half of the yet unclosed neural arch and in the centrum of the vertebral body. There may be hereditary factors, which as yet are not well defined. It is noted that cervical and lumbar stenosis may not uncommonly be seen in the same patient.

\section{TABLE I}

The series

\begin{tabular}{lcccrrr}
\hline & & & \multicolumn{2}{c}{ Age (years) } & \multirow{2}{*}{ Total } \\
\cline { 2 - 4 } & 40 & $4 \mathrm{I}-50$ & $5 \mathrm{I}-60$ & 60 & \\
\hline Male & 0 & 8 & $\mathrm{I} 5$ & $\mathrm{I} 5$ & 38 \\
Female & 0 & $\mathrm{I}$ & 3 & 3 & 7 \\
Total & 0 & 9 & $\mathrm{I} 8$ & $\mathrm{I} 8$ & 45 \\
\hline
\end{tabular}




\section{Acquired}

Acquired forms of cervical spinal stenosis is seen in various conditions, but in particular in some patients with cervical spondylosis and in some with a cervical intervertebral disc protrusion. Also in achondrodysplasia, with certain spinal neoplasms, after spinal trauma, as a complication of Paget's disease of bone, and in subluxations of the cervical spine with ageing.

The close association of a narrowed spinal canal in patients with cervical spondylotic myelopathy (Payne \& Spillane, I957), is confirmed and fully accepted.

\section{Vascular}

\section{Mechanisms and Biomechanics}

It is considered that there is claudication of the cervical spinal cord with neck movements. As long ago as I9I I, Dejerine described what he termed 'intermittent claudication of the spinal cord'. Fibres of the cortico-spinal and spino-thalamic tracts in the lateral white columns are particularly vulnerable; and this would appear to be related to the blood supply of these regions from perpendicular perforating vessels of the pial anastomotic arterial network.

\section{Mechanical}

It is remarkable to see the effects of spinal movement, and in particular flexion and extension, on all spinal structures, altering the length of the vertebral column and the length of the theca and its contents both spinal cord and nerve roots, and also of blood vessels (Brieg, I960). Extension may result in a 9-I7 per cent or more reduction in diameter of the spinal canal and a 25 per cent reduction in the diameter of the intervertebral foraminae, and about is per cent reduction in diameter of the spinal cord (Waltz, I967).

\section{Vascular and Mechanical}

In the individual patient both vascular and mechanical factors may be important but in what proportions is not known.

\section{Clinical}

\section{Diagnosis}

The clinical symptoms and signs are varied and variable, and it is likely that there is more than one syndrome in this condition of cervical spinal canal stenosis. However, leg cramps and tiredness of the legs especially when walking upstairs are commonly noted, and paraesthesiae of the hands are also quite common. Neck pain may occur.

There are myelopathic syndromes: $(a)$ sudden without regression, or $(b)$ brief transient episodes.

These syndromes may be aggravated by physical activity. Severe, crisp sensory changes are unusual, as are disturbances of bowel, urinary bladder or of sexual functions (Table II).

\section{Radiological}

I recommend that cervical spine radiographs should be taken at a standard distance, $e . g .72 \mathrm{~cm}$. Plain lateral radiographs are taken with the patient's neck in a 'neutral' position, then fully flexed and then fully extended. Lateral tomography 


\section{TABLE II}

Clinical features

\begin{tabular}{lcc}
\hline \multicolumn{1}{c}{ Syndrome } & No. of patients \\
\hline Neck & \multicolumn{2}{c}{ I6 } \\
$\quad$ Pain; stiffness & \multicolumn{2}{c}{} \\
Radicular & I2 & \\
$\quad$ Unilateral & IO & 22 \\
Bilateral & & \\
Myelopathy & 5 & \\
Anterior cord & 8 & \\
Lateral cord & 0 & \\
Central cord & 0 & \\
Posterior cord & I8† & $3 \mathrm{I}$ \\
$\quad$ Subtotal cord & & 3 \\
Vertebral-basilar insufficiency & & \\
\hline
\end{tabular}

* It is noted that several patients had 'mixed' syndromes.

$\dagger$ Four of the patients in this category had neuropathic bladder disorder.

should also be done. Myelography (Fig. I), preferably using a positive contrast medium, is essential-to demonstrate soft tissue, non-radio-opaque encroachment on the spinal canal and intervertebral foraminae, such as an intervertebral disc

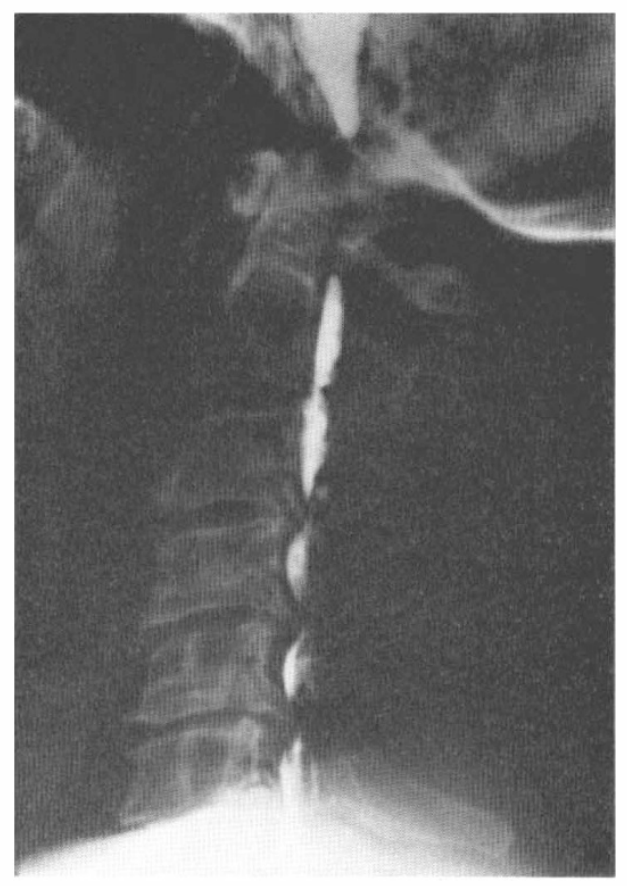

FIG. I

Lateral cervical myelogram showing evidence of severe cervical spondylosis and stenosis. 
protrusion, ligamentum flavum and the dura mater; again views in full flexion and in full extension are necessary. Computerised axial tomography (C.A.T.) of the spine is now becoming available and will be a most valuable safe and non-invasive investigation for many spinal disorders and certainly for cervical spinal stenosis; horizontal 'sections' of the spine, taken at different levels, clearly show the diameter of the spinal canal, and it is now becoming possible to carry out longitudinal studies of the spine using C.A.T.

In the series of patients discussed in this paper, two measurements have been made of the antero-posterior diameter of the spinal canal: (I) using plain radiographs; and (2) using myelograms:

(a) the distance from the postero-inferior edge of the vertebral body above and the site of fusion of the lamina and spine of the vertebra caudal to this vertebra.

(b) the distance from posterior aspect of the centre of the vertebral body to the cortical line (base) of the spinous process of the same vertebra.

The criteria used to arrive at a diagnosis of cervical spine stenosis in this series are-in the plain radiographs an antero-posterior diameter of $12 \mathrm{~mm}$ or less, and in the myelograms in over 50 per cent of the patients the antero-posterior diameter 4-6 mm less than this, that is $8-6 \mathrm{~mm}$-representing the 'soft, non-radio-opaque tissues' such as protruded intervertebral disc; thickened anterior, thickened posterior common ligaments; infolded dura mater; infolded ligamentum flavum.

\section{Other Investigations}

Evoked potential studies, and estimation of the H-reflex are also being done.

\section{Criteria for Operative Treatment}

Pre-operative factors considered to be important include:

Length of history. The best results with operative treatment are obtained in those patients where the history is a year or less.

Degree and type of neurological abnormality. Patients with an anterior cord syndrome or a subtotal cord syndrome respond best to operative treatment. Those with a central cord syndrome, or a posterior cord syndrome do less well, and indeed surgical treatment is contra-indicated in such patients.

Radiological features. All pathological changes seen in radiographs of the cervical spine play some part in the production of the clinical syndrome and have a bearing on the results of operative decompression of the contents of the spinal canal. The importance of individual abnormalities, including the reduction or loss of cervical lordosis, canal narrowing, foraminal narrowing, osteophytes etc., is not yet known.

Age and sex of the patient. As far as can be ascertained from the present study, the age of the patient per se is not of special importance. Neither is the sex of the patient.

\section{Aims and Types of Operation}

The intention is to decompress the neural and vascular structures in the affected portion of the cervical spine and to ensure that the spine is left quite stable and that any cervical lordosis or retrolisthesis is corrected. 
Different operations are available, but the choice of operation or operations for any individual patient has not yet, in the literature, been well defined (Galera \& Tovi, I968); although with a large enough series of patients studied in detail over a long enough period of time, it is now becoming possible to be selective concerning the type of patient who should benefit from operative treatment and the type of operation that should be applied for that particular patient. To the knowledge of the author of this paper, very little has been written to date about this subject. Kessler (1975) said that an anterior operation on the cervical spine may result in complications arising if it was necessary to operate on two or more segments; for this reason, he advises a wide laminectomy as the best form of treatment.

As will be seen from Table III, different types of operation have been carried out on these 45 patients, including extensive anterior decompressive-fusion procedures, extensive decompressive laminectomies and indeed in several patients both of these operations have been carried out on the same patient, the second procedure following the first after an interval of several weeks or longer.

\section{Results}

Set out in Table IV is the type of neurological syndrome that the patient had, and the result of operative treatment. The length of the history and the radiological features also influence the result of the particular type of operation or operations that were carried out. Careful follow-up studies are made, 6 weeks after operation, then at 3 months, at 6 months, and then once a year. All of the patients have been followed up for at least I year, several for up to I3-I5 years (Table V).

Thirteen patients fully recovered, eight with radicular and five with myelopathic syndromes; and a further 24 made a 'good' recovery; three had a radicular, and I8 a myelopathic syndrome.

\section{TABLE III}

Operations

Anterior decompression and bony fusion

\begin{tabular}{lccccc}
\hline \multicolumn{1}{c}{ No. of discs } & I & $\mathbf{2}$ & 3 & 4 & Total \\
\hline One operation & $3(3)$ & - & $27(6)$ & 5 & $35(9)$ \\
Second operation & - & - & 3 & I & 4 \\
$\quad$ Total & $3(3)$ & - & $30(6)$ & 6 & $39(9)$ \\
\hline
\end{tabular}

N.B. Patients in parentheses also had a decompressive laminectomy.

Decompressive laminectomy as the only surgical procedure

\begin{tabular}{llllc}
\hline No. of laminae removed & 3 & 4 & 5 & Total \\
No. of patients & I & 3 & 2 & 6 \\
\hline
\end{tabular}




\section{TABLE IV}

Results

\begin{tabular}{lccc}
\hline \multirow{2}{*}{ Result } & \multicolumn{2}{c}{ Syndrome } & \multirow{2}{*}{ Total } \\
\cline { 2 - 3 } & Radicular & Myelopathic & \\
\hline Full recovery & 8 & 5 & I3 \\
Partial recovery & & I8 & 2I \\
$\quad$ Good & 3 & 6 & 6 \\
$\quad$ Limited & - & 3 & 3 \\
Unchanged & - & 2 & 2 \\
Worse (slightly) & & 34 & 45 \\
$\quad$ Total & I I & 34 & \\
\hline
\end{tabular}
disease.

* The clinical deterioration was compatible with the preoperative trend of the

$$
\text { TABLE V }
$$

Follow-up studies

\begin{tabular}{lcccccc}
\hline Follow-up period (years) & I & I-3 & $4-5$ & $6-8$ & $9-\mathrm{I} 2$ & I3-I5 \\
No. of patients & 7 & I4 & 2 & II & 4 & 7 \\
\hline
\end{tabular}

\section{Complications}

There has been no mortality, and no significant neurological complications.

\section{SUMMARY}

The aetiology of the condition called 'cervical spinal canal stenosis' is discussed, along with the various clinical syndromes that may develop, and mention has been made of the radiological techniques that are used and are recommended for the study of these patients.

For this study, 45 patients who had cervical spine stenosis resulting from cervical spondylosis are discussed.

With a detailed study of a sufficient number of these patients, and a meticulous clinical and radiological follow-up over a period of several years, it is now becoming possible to recommend particular forms of operation for patients with syndromes severe enough to warrant operative treatment.

It is stressed that most assiduous clinical and radiological follow-up examinations are necessary, because in some of these patients an additional operation may be required to halt the patient's clinical deterioration, and in several to improve their clinical state.

\section{RÉSUMÉ}

On discute l'étiologie de l'état appelé 'sténose du canal rachidien cervical', de même que les différents syndromes cliniques pouvant se développer, et on mentionne les techniques radiologiques utilisées et recommandées pour l'étude de ces patients. 
Pour cette étude, on discute 45 patients atteints de sténose de la colonne cervicale résultant d'une spondylose cervicale.

Grâce à une étude détaillée d'un nombre suffisant de ces patients, et après un suivi clinique et radiologique méticuleux pendant plusieurs années, il devient possible désormais de recommander des types particuliers d'opérations aux malades présentant des syndromes assez graves pour justifier un traitement opératoire.

On insiste sur la nécessité d'un suivi clinique et radiologique assidu parce que, chez certains de ces patients, une opération supplémentaire peut s'imposer pour arrêter une détérioration clinique de l'état des malades, et dans plusieurs cas, pour améliorer leur état clinique.

\section{ZUSAMMENFASSUNG}

Die Aetiology der sogenannten 'Spinalen Cervikal-Stenose' wurde in Zusammenhang mit versehiedenen Syndromen diskutiert. Radiologische Techniks, die angewandt werden, sind erwähnt und für die Untersuchung dieser Patienten empfholen. 45 Patienten mit cervikaler spinaler Stenosis als Folge von cervikaler Spondylosis werden diskutiert. Es ist jetzt möglich, bestimmte Operationen zu emphfehlen für Patienten mit schweren klinischen Symptomen.

Acknowledgements. I have great pleasure in thanking my Consultant Radiological colleagues Dr A. A. Donaldson and Dr G. T. Vaughan for all their assistance, and Major V. S. Madan, F.R.C.S., for his invaluable help with the analysis. This work was carried out with the help of a Grant from the Secretary of State of Scotland through the Advisory Council for Medical Research, to whom I am most grateful.

\section{REFERENCES}

BRAIN, W. R. (I954). Spondylosis, the known and the unknown. Lancet, I, 687.

BREIG, A. (1960). Biomechanics of the Central Nervous System: some basic normal and pathologic phenomena. Almquist and Wiksill: Stockholm.

Dejerine, J. (I9II). Claudication Intermittente de La Moelle Epiniere. Pr. Med. 19, 98I-984.

GALERA, R. G. \& Tovi, D. (I968). Anterior disc excision with interbody fusion in cervical spondylotic myelopathy and rhizopathy. F. Neurosurg. 28, 305-3IO.

Harris, P. (1963). The anterior approach to excision of cervical discs. Proc. Roy. Soc. Med. 56, 807-808.

KessLer, J. T. (1975). Congenital narrowing of the cervical spinal canal. F. Neurol. Neurosurg. Psychiat. 38, 1218-1224.

Payne, E. E. \& Spillane, J. D. (I957). The cervical spine. An anatomico-pathological study of 70 specimens (using a special technique) with particular reference to the problems of cervical spondylosis. Brain, 80, 57I-596.

WaLTZ, T. A. (1967). Physical factors in the production of the myelopathy of cervical spondylosis. Brain, 90, 395-404.

\section{General Discussion}

DR HARDY (Chairman). I would like to hear anything from the floor on this very interesting paper. In fact I'll ask one question straightaway. I am of course clear that these procedures have to be done, Phillip. I'm just wondering whether the fusion in these cases which inevitably must produce one of the predisposing factors to susceptibility to minor injury. Have you in actual fact found that you had a minor injury producing as I called it a major disaster because you have got this ankylosed spine?

Mr HARRIS. In the patients we've been able to follow up-of course some of these patients are not young and they will die from various causes-but so far we've not come across this. But in my 500-odd patients which are now going through a computer and will come out in a monograph, to my knowledge there are four patients who have required a second operation as trouble has occurred at a higher level because of compensatory movement, but we have had none who have suffered from any injury that 
we know about and we would know about them because they are all pretty well in our vicinity.

DR HUSSEY (U.S.A.). Have you noticed spontaneous regression of the osteophitic spurs upon attaining satisfactory fusion over a period of time?

Mr HARRIS. Smith and Robinson in Baltimore advocated this, and I watched them do this many years ago; and the Guys Hospital people in London are doing this. The Smith-Robinson operation I really can't accept as I don't think it is appropriate.

DR F. W. MEINECKE (Germany). May I ask one question with regard to the actual computer tomography. Do you have personal experience with this method in the spinal cord and do you feel that this method can probably replace all the other diagnostic methods as we are expecting in brain injury?

Mr HARRIS. I speak without any real practical personal knowledge. My knowledge is second hand. These machines are pretty expensive, in Britain they cost about $£ 450,000$, the head scanner costs about $£ 250,000$. Therefore, this is the thing for the future. There is no doubt at all that this will bring a tremendous advance to our study of the spinal cord, and spinal canal.

DR HARDY. Do you have a whole body scanner in Sunnybrook Dr Tator ?

DR TATOR. No. 